\title{
Bulanık Yapay Sinir Ağları ve Çok Katmanlı Yapay Sinir Ağları ile Günlük Buharlașma Tahmini
}

\author{
Demet YILDIRIM 1,* (iD) \\ Bilal CEMEK² (iD) \\ 'Karadeniz Tarımsal Arașt. Enst. Tarımsal Sulama ve Arazi Isı. Birimi, Samsun
2Ondokuz Mayıs Üniversitesi. Tarımsal Yapılar ve Sulama Anabilim D., Samsun
}

Erdem KÜÇÜKTOPCU² (iD)

*Sorumlu yazar (Corresponding author) e-mail: demet.yildirim@tarimorman.gov.tr

Geliș tarihi (Received): 11.10.2017

Kabul tarihi (Accepted): 09.07.2019

DOI: 10.21657/topraksu. 654778

\section{Öz}

Hidrolojik döngü için buharlașma önemli parametrelerden biridir. Buharlașma su döngüsü ve sulama yönetimi gibi birçok çalıșma için kullanılır. Buharlașmayı hesaplamak için çeșitli yaklașımlar geliștirilmiștir. Bu çalıșmada farklı iklim parametreleri kullanılarak günlük buharlașmayı tahmin etmek için Yapay Sinir Ağları (YSA) ve Uyarlamalı Ağ Yapısına Dayalı Bulanık Çıkarım Sistemi (ANFiS) yöntemleri kullanılmıștır. Bu metotlarda test ve eğitim verisi olarak 3 meteoroloji istasyon (Samsun. Bafra ve Çarșamba) verisi kullanılmıștır. Ortalama sıcaklık, bağı nem, güneșlenme șiddeti ve rüzgâr hızı farklı kombinasyonlar da tahmin için kullanıımıștır.

Belirtme katsayısı (R2), tahmin hatasının standart sapması (RMSE), ortalama mutlak hata (MAE) gibi farklı istatistik parametreleri kullanılarak model performansını değerlendirilmiștir. Sonuç olarak YSA ve ANFis metotları özellikle sınırlı iklim parametrelerinin olduğunda buharlașmayı tahmin etmede yararlı araçlardan olduğu belirlenmiștir.

Anahtar Kelimeler: ANFIS, günlük buharlașma, Samsun, yapay sinir ağları

\section{Estimation of Daily Evaporation Using Fuzzy Artificial Neural Network (ANFIS) and Multilayer Artificial Neural Network System (YSA)}

\section{Abstract}

Evaporation is one of the important parameters of hydrolojical cycle. Evaporation is used for many studies. such as water balange. planning and management of irrigation practices. In order to estimate of evaporation is used various approachs. Instudy Artifical Neural Network (ANN) and Adaptive NeuroFuzzy İnference System (ANFIS) is employed to estimate daily evaporation using different climatic parameters. For these methods are trained and tested using the data of three weather stations (Samsun, Bafra and Çarșamba). Mean temperature, relative humidity, global radiation, wind speed are used to estimate different conbination for these models. Different statistic parameters such as coffecient of determination (R2), root mean square error (RMSE), mean absolute error (MAE) are used to evaluate performance of the methods. The results showed that ANN and ANFis methods are useful tools to estimate of evaporation especially when the limited climate parameters are used.

Keywords: Adaptive neuro-fuzzy inference system, daily evaporation, Samsun, artifical neural network 


\section{Gíriș}

Buharlașma su kaybı olarak su kaynakları yönetiminde ve gelișimde bir referans olup buharlașma oranını tahmini hidroloji planlanmasında oldukça önemli unsurlardan birisidir. Buharlașma yeryüzünde sıvı ve katı halde farklı șekillerde bulunan suyun meteorolojik faktörlerin etkisinde kalarak atmosfere gaz halinde geçișidir. Yeryüzüne düșen yağıșın önemli bir bölümü buharlașma ve terleme yoluyla atmosfere geri kazanılır. Bu kayıpların belirlenmesi ve özellikle kurak mevsimler için hidrolojik olarak önem arz etmektedir. Buharlașma, güneș radyasyonu, sıcaklık, rüzgâr hızı, nem, atmosferik basınç ve çevresel koșulların etkilediği bir parametredir. Son yıllarda teknolojik anlamda özellikle bilgisayar alanında ilerlemeler hızı bir șekilde artmaktadır. Bu gelișmeler sayesinde insanlar birçok alanda yaptıkları çalıșmalarda hızlı olmakta ve zamandan kazanç sağlamaktadır.

İklim verilerinin kullanımı tarımsal faaliyetler ve meteoroloji için çok önemlidir. Farklı yöntemler kullanılarak eksik olan iklim verilerinin belirlenmektedir. Ancak, bu iklim verilerinin sadece klasik istatistiksel yöntemlerle incelenmesi yeterli olmamaktadır.

Ayrıca son yıllarda toprak su ve iklim parametreleri dikkate alınarak mevcut verilerden istenilen bașka bir verinin tahmin edilmesinde yapay zeka teknikleri sıklıkla kullanılmaya bașlanmıștır. Günlük buharlașma tahmini, bitki su tüketimi (ET)' nin belirlenmesinde alternatif bir yol Yapay Sinir Ağları (YSA) ve Uyarlamalı Ağ Yapısına Dayalı Bulanık Çıkarım Sistemi (ANFiS) gibi matematiksel modellerin uygulanmasıdır. YSA mimarisi biyolojik sinir ağlarından esinlenerek geliștirilmiș bir modeldir. Son yıllarda farklı bilimsel uygulamalarda bilgisayar teknolojilerinin gelișimi nedeniyle kendi alanında önemli bir artıș olmuștur.

YSA ve ANFis gibi farklı nemler ile buharlașmanın tahmininde farklı çalıșmalar yapılmıștır. Bu çalıșmalar; Kiși (2006) yapay sinir ağları ile farklı meteorolojik verileri kullanarak buharlașmanın modellenmesi tahmin etmiștir. Sudheer vd. (2002) çok değișkenli hidrolojik modellerin olușturulmasında Radyal tabanlı yapay sinir ağlarını kullanarak gölde meydana gelen günlük buharlașmayı tahmin etmișlerdir. Terzi ve Keskin (2005) yapay sinir ağlarında genelleștirilmiș regresyon modeli ile A sınıfı tava buharlașma tahmini yapmișlardır. Doğan ve ıșık (2005), Cemek vd. (2010), Boroomand - Nasab ve Joorabian (2011), Cemek vd. (2011), Chung vd. (2012), Atiaa ve Abdul - Oadir (2012) ve Karimi - Googhari (2012) yaptıkları çalıșma farklı meteorolojik parametreleri kullanarak YSA ve ANFiS ile buharlașma tahmini yapmıșlardır.

Çalıșmada 3, 4 ve 5 girdi kullanarak YSA için farklı algoritmalar kullanarak ve ANFiS için farklı üyelik fonksiyonları kullanarak günlük buharlașma tahmini yapılmıștır. YSA modelinde LM ve SCG eğitim algoritması, tek katmanlı ve çift katmanlı ağ yapısı kullanarak 200, 400 ve 600 iterasyon sayında tahminler yapılmıș ve model performanslarına göre en iyi model belirlenmiștir. ANFiS için farklı girdiler yanında trimp, tramp, gausemf, gausemf2 gibi farklı üyelik fonksiyonlarında model performansları belirlenmiș ve en yüksek R2, en düșük RMSE ve MAE değerlerine göre en iyi model belirlenmiștir.

Bu çalıșma YSA ve ANFis yönteminin ideal olmayan koșullar için hızlı, pratik sonuçlar üretebilen, yüksek doğrulukta tahmin yapabilen ve geleneksel yöntemlerden daha iyi sonuçlar verdiği görülmektedir.

\section{MATERYAL VE YÖNTEM}

Bu çalıșmada Samsun için 1968-2008, Bafra için 1985-2006 ve Amasya için 1983-2010 yılları arasında meteorolojik veriler kullanılmıștır. Meteorolojik veri olarak ortalama sıcaklık, nem, rüzgar hızı, global güneșlenme ve yağıș kullanılmıștır. Bu meteorolojik veriler girdi olarak Yapay Sinir Ağları (YSA) ve Uyarlamalı Ağ Yapısına Dayalı Bulanık Cıkarım Sistemi (ANFIS) modellerinde kullanılarak günlük buharlașma tahmin edilmiștir.

\section{Yapay sinir ağları (YSA)}

Yapay Sinir Ağları (YSA), insan beyninin özelliklerinden olan öğrenme yolu ile yeni bilgiler türetebilme ve keșfedebilme yeteneklerine bir yardım almadan otomatik olarak gerçekleștirmek için geliștirilen bir bilgisayar sistemidir. Sinir sisteminden yararlanılarak ortaya çıkarılan YSA paralel çalıșma ve eğitebilme yeteneklerini kullanarak biyolojik sinir sistemine benzerlik gösterir. YSA ile bilgileri çok kolay ve hızlı bir șekilde ișlenmesi sağlanır ve diğer yöntemlere göre daha cazip olmasını sağlar. 
Bu ağlar öğrenme, hafızaya alma ve veriler arasındaki ilișkiyi ortaya çıkarma kapasitesine sahiptirler. YSA, 1943 yılında yapay sinir tanımını yaparak Șekil 1' deki gibi bir hücre modeli geliștiren McCullogh ve Pitts tarafından bașlatıldığı kabul edilir (McCullogh ve Pitts. 1943). Çalıșmalarında sinir hücrelerini sabit eșik değerli mantıksal elemanlar olarak modellemișlerdir. Daha sonra öğrenme üzerine çalıșmalarınyoğunlaștığı 1949 yılında Hebb, yapay sinir ağlarındaki öğrenme için bașlangıç noktası sayılabilecek bir kuralı geliștirmiștir (Hebb. 1949). Genel olarak hücreler 3 katman halinde ve her katman içinde paralel olarak bir araya gelerek ağı oluștururlar. Bu katmanlar; Girdi Katmanı. Ara Katmanlar (Gizli Katman) ve Çıktı Katmanı' dır. Bir yapay sinir hücresi (nöron), kendisine gelen bir giriș değerini, kendisine gelen birden fazla bağlantıya ait ağırlık değerleri ile çarparak toplamını hesaplar. Sonra toplam değerini etkinlik fonksiyonundan geçirerek bir sonraki katmana çıkıș olarak iletir. Çok katmanlı ağlarda, ara katmanlarda genellikle sigmoid etkinlik fonksiyonu, çıkıs katmanında ise lineer etkinlik fonksiyonu kullanılır. Basit bir Yapay sinir ağları modeli Șekil 1' de verilmiștir (Jang, 1993).

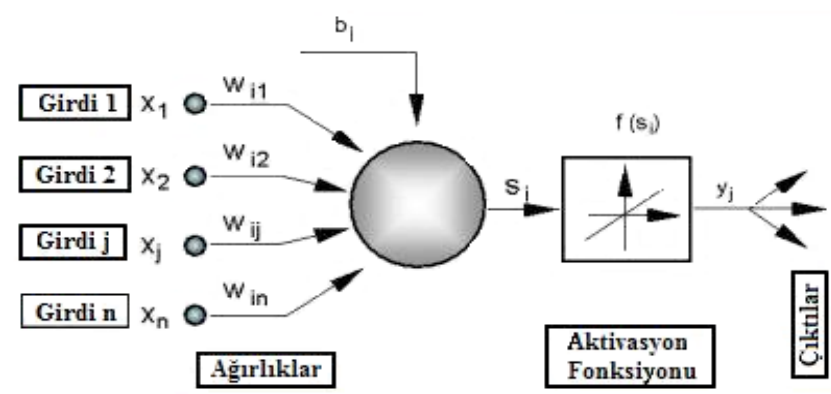

Șekil 1. Basit bir sinir ağları modeli

Figure 1. A simple neural network model

\section{Uyarlamalı ağ yapısına dayalı bulanık çıkarım sistemi (ANFis)}

Uyarlamalı Ağ Yapısına Dayalı Bulanık Cııarım Sistemi (Adaptive-Network Based Fuzzy Inference Systems-ANFIS), yapay sinir ağlarının paralel hesaplayabilme ve öğrenme kabiliyeti ile bulanık mantığın çıkarım özelliğini ortak kullanan bir yapay zeka yöntemidir. Jang (1993) tarafından 1993 ylında geliștirilmiș olan ANFIS model Sugeno tipi bulanık çıkarım sistemini ve Melez öğrenme (Hybrid learning) algoritmasını kullanır. Uyarlamalı ağlar, doğrudan bağlanmıș düğümlerden olușur ve bu düğümler, bir ișlem birimini gösterir. Düğümler arasındakibağlantılar, aralarındaki değeritamolarak belli olmayan bir ilgiyi (ağırlığı) gösterir. Adaptif ağlar, sistem tanımlama için kullanılır. Verilen girișçıkıș veri setleriyle tanımlanan bilinmeyen sistemin, en uygun ağ yapısı ve parametre setleriyle en iyi șekilde modellenmesinde kullanılır. Șekil $2^{\prime}$ de ANFis modeli șekilsel olarak gösterilmiștir.

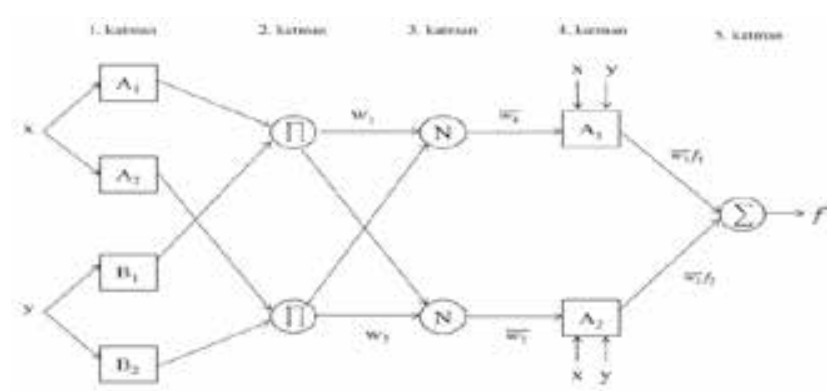

Șekil 2. ANFiS Modeli (Jang. 1993)

Figure 2. ANFiS model (Jang. 1993)

Bu çalıșmada YSA ve ANFIS' de meteorolojik veriler girdi olarak kullanılmıș farklı kombinasyonlar ile olușturulan modellerde günlük buharlașma tahmin edilmiștir. YSA ve ANFiS modellerinde farklı kombinasyonlar Çizelge 1' de verilmiștir. Modeller için YSA' da tek katmanlı ve çift katmanlı ağ yapiları kullanıımıștır. Tek katmanlı ağ yapılarında $6 * 1,8 * 1$, $10 * 1$, çift katmanlı $6 * 10 * 1,8 * 10 * 1$ ve $10 * 10 * 1$ ağ yapılarında ișlem yapılımıștır. Levenberg-Marquardt (LM) ve Scaled conjugate gradient (SCG) gibi iki farklı eğitim algoritması kullanılarak elde edilen sonuçlar. 200-400-600 kez iterasyon yapılarak hesaplanan değerler ile karșılaștırılmıștır.

Çizelge 1. YSA ve ANFiS modellerinde kullanılan girdiler Table 1. Sinputs used in ANN and ANFis models

\begin{tabular}{cccccc}
\hline & $\begin{array}{c}\text { Ort. } \\
\text { Sıcaklık }\end{array}$ & Nem & $\begin{array}{c}\text { Rüzgâr } \\
\text { Hızı }\end{array}$ & $\begin{array}{c}\text { Gün. } \\
\text { Șiddeti }\end{array}$ & Yağıș \\
\hline YSA $_{1}$ & $\checkmark$ & $\checkmark$ & $\checkmark$ & $\checkmark$ & \\
YSA $_{2}$ & $\checkmark$ & $\checkmark$ & $\checkmark$ & $\checkmark$ & \\
YSA $_{3}$ & $\checkmark$ & $\checkmark$ & $\checkmark$ & $\checkmark$ & $\checkmark$ \\
ANFiS $_{1}$ & $\checkmark$ & $\checkmark$ & $\checkmark$ & $\checkmark$ & \\
ANFiS $_{2}$ & $\checkmark$ & $\checkmark$ & $\checkmark$ & $\checkmark$ & \\
\hline
\end{tabular}

\section{BULGULAR VE TARTISMA}

Calıșmada YSA ve ANFis modelleri için ortalama sıcaklık. nem, rüzgar hızı, global güneșlenme ve yağıș verileri farkı kombinasyonlarda kullanılarak günlük buharlașma tahmini yapılmıștır. Meteorolojik verilerin test ve eğitim verilerinin özet istatistik parametreleri; en büyük, en küçük, ortalama değer, çarpıklık ve standart sapma değerleri Çizelge 2 ' de verilmiștir. 
Çizelge 2. Test ve eğitim verilerinin özet istatistik parametreleri

Table 2. Summary statistical parameters of test and training data

\begin{tabular}{|c|c|c|c|c|c|c|c|c|}
\hline Așama & & Değișkenler & En büyük & En küçük & Ortalama & Std Sapma & CV & Carpıklık \\
\hline \multirow{6}{*}{ Test } & \multirow{6}{*}{ Amasya } & Ort. Sıcaklık & 26.4 & 8 & 19.14 & 4.32 & 22.57 & -0.307 \\
\hline & & Nem & 76 & 41.2 & 55.63 & 6.07 & 10.91 & 0.516 \\
\hline & & Rüzgâr Hızı & 3.1 & 0.9 & 1.55 & 0.369 & 23.81 & 0.877 \\
\hline & & Global Gün. & 144.6 & 0 & 13045.01 & 3233.655 & 24.79 & -0.739 \\
\hline & & Yağıș & 144.6 & 0 & 36.62 & 30.79 & 84.08 & 1.198 \\
\hline & & Gün. Buh. & 8.4 & 0.7 & 4.586 & 1.733 & 37.79 & 0.109 \\
\hline \multirow{12}{*}{ Eğitim } & \multirow{6}{*}{ Samsun } & Ort. Sicaklık & 26.50 & 3.10 & 16.29 & 5.51 & 33.82 & -0.17 \\
\hline & & Nem & 86.00 & 55.80 & 74.64 & 5.45 & 7.30 & -0.50 \\
\hline & & Rüzgâr Hızı & 5.4 & 1.00 & 2.17 & 0.61 & 27.97 & 1.72 \\
\hline & & Global Gün. & 19264.20 & 2638.91 & 10453.68 & 4418.48 & 42.27 & -0.12 \\
\hline & & Yağıș & 257.00 & 0.00 & 55.93 & 38.43 & 68.71 & 1.31 \\
\hline & & Gün. Buh. & 6.10 & 1.00 & 3.10 & 1.26 & 40.74 & 0.41 \\
\hline & \multirow{6}{*}{ Bafra } & Ort. Sicaklık & 25.00 & 5.80 & 16.48 & 4.75 & 28.82 & -0.23 \\
\hline & & Nem & 87.30 & 66.70 & 76.60 & 4.26 & 5.56 & 0.07 \\
\hline & & Rüzgâr Hızı & 4.10 & 0.50 & 1.71 & 0.55 & 32.22 & 0.70 \\
\hline & & Global Gün. & 17948.55 & 2708.90 & 11015.95 & 3896.41 & 35.37 & -0.48 \\
\hline & & Yağıș & 343.90 & 0.00 & 63.85 & 52.33 & 81.96 & 1.87 \\
\hline & & Gün. Buh. & 7.10 & 0.90 & 3.51 & 1.44 & 41.03 & 0.15 \\
\hline
\end{tabular}

Çalıșmada farklı girdiler kullanılarak YSA ve ANFis uygularında farklı kombinasyonlar da farklı modeller olușturulmuștur. Modellerde Samsun ve Bafra buharlașma verileri eğitim verisi. Amasya buharlașma değerleri ise test verisi olarak kullanılmıștır. Toplamda 472 veri eğitim, 181 veri ise test verisi olarak kullanılmıștır. Farklı kombinasyonlar için buharlașma tahmin edilmiș ve performans göstergeleri hesaplanarak karșılaștırılması yapılımıștır (Çizelge 3). YSA' da LM eğitim algoritmasında elde dilen model sonuçları SCG eğitim algoritmasından daha iyi olduğu belirlenmiștir. 3, 4, 5 girdi kullanılan tek katmanlı $\left(6^{*} 1,8^{*} 1\right.$ ve $\left.10^{*} 1\right)$ model sonuçlarının çift katmanlı $(6 * 10 * 1.8 * 10 * 1$ ve $10 * 10 * 1)$ model sonuçlarına göre daha yüksek $R^{2 \prime}$ ye sahip olduğu elde edilmiș. Ortalama sıcaklık. nem. rüzgar hızı ve global güneșlenme girdileri kullanılan LM eğitim algoritmasında. 600 iterasyon yapılarak $8 * 1$ tek katmanlı ağ yapısına sahip $4 * 8 * 1$ modelinde en yüksek $R^{2}(0.868)$ en düșük RMSE (0.713) ve MAE (0.661) değeri elde edilmiș ve en iyi buharlașma tahmininin yapıldığı model olarak belirlenmiștir. Günlük buharlașmanın YSA' ya göre en iyi tahmin edilen $4{ }^{*} 8 * 1$ model performans sonuçları Șekil $3^{\prime}$ verilen grafik ile sunulmuștur. SCG eğitim algoritmasında tek katmanlı 8*1 ağ yapısında ortalama sıcaklık, nem, rüzgar hızı, global güneșlenme ve yağıș girdilerinin kullanıldığı YSA3 $(5 * 8 * 1)$ modelinde yüksek doğrulukta $\left(R^{2}\right.$ 0.85) günlük buharlașma tahmini yapılımıștır.

ANFiS' de YSA' da olduğu gibi 3. 4 ve 5 girdi kullanılmıs ve trimp, tramp, gausmf ve gausmf2

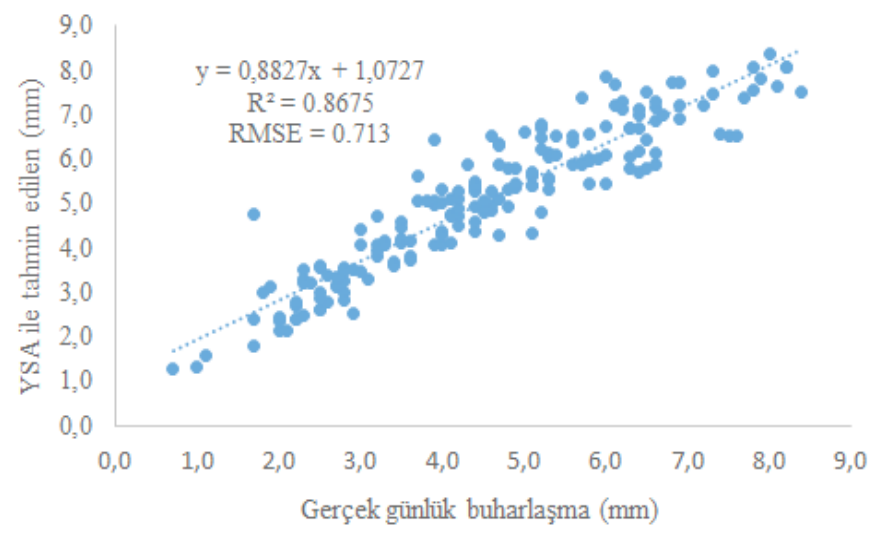

Sekil 3. YSA ile tahmin edilen $4 * 8 * 1$ modelinin performans grafiği Figure 3. Performans chart of $4{ }^{*} 8 * 1$ model estimated by ANN

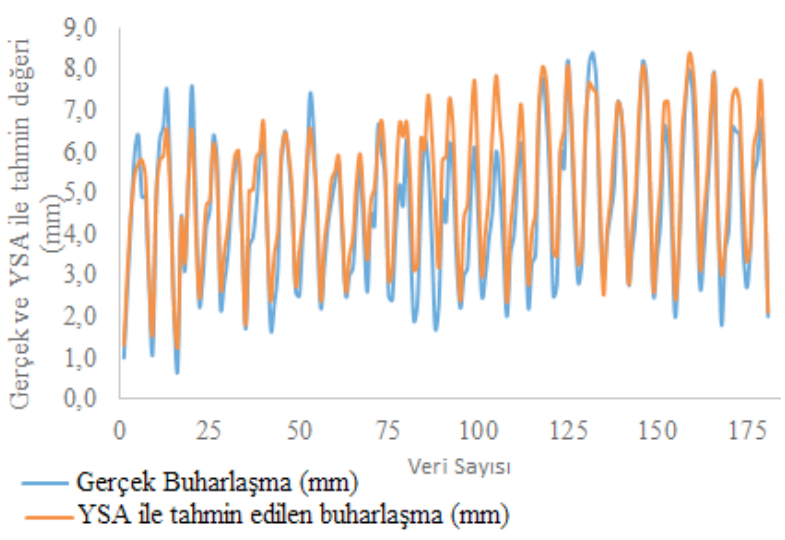


Çizelge 3. Yapay sinir ağları model performanslarının karșılaștırılması

Table 3. Comparison of artificial neural network model performance

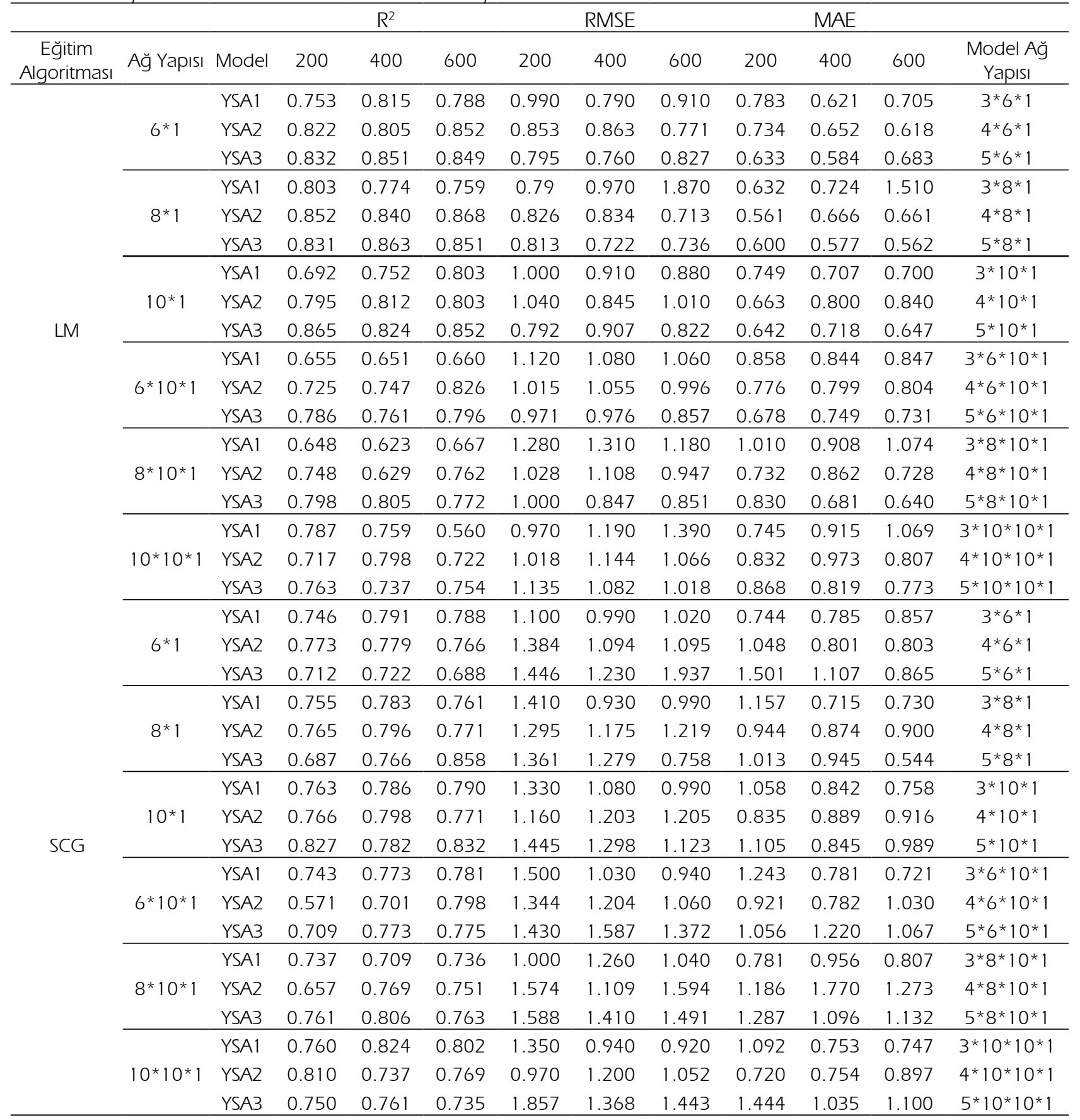

gibi farklı üyelik fonksiyonlarında günlük buharlașmanın tahmini yapılmıștır. Model performans sonuçları Cizelge 4' de verilmiștir. 4 ve 5 girdi ile olușturulan ANFis $_{2}$ ve $\mathrm{ANFiS}_{3}$ modellerinde ANFisı modeline göre daha yüksek sonuçlar elde edilmiștir. Ortalama sıcaklık, nem, rüzgar hızı, global güneșlenme ve yağıș girdilerinin kullanıldığı gausmf üyelik fonksiyonun da $\mathrm{ANFIS}_{3}$ modelinde en iyi günlük buharlașma tahmin edilmiștir. $\mathrm{ANFiS}_{3}$ modelinde gerçek ve tahmin edilen buharlașma karșılaștırıldığında 0.994 R2, 0.124 RMSE ve 0.072 MAE değerleri elde edilerek yüksek doğrulukta sonuç belirlenmiștir. En yüksek doğrulukta tahmin edilen $\mathrm{ANFiS}_{3}$ model performans grafiği Șekil 4' de verilmiștir.

Çalıșmada YSA ve ANFIS için çıkan en iyi modeller değerlendirilerek Samsun ili ve Bafra ilçesi için günlük buharlașma tahmini yapılmıștır. YSA' da LM eğitim algoritmasında $4{ }^{*}{ }^{*} 1$ ağ 
yapısına sahip model. ANFis de 5 girdiye gausmf üyelik fonksiyonuna sahip 3. model ile tahmin yapılmıș ve model performansı Șekil 5 ve Șekil 6' da verilmiștir. Test ve eğitim verilerine göre YSA ve ANFis de seçilen en iyi model performansları Çizelge $5^{\prime}$ de verilmiștir. YSA. Samsun için $4 * 8 * 1$ model sonucunda günlük buharlașma

Çizelge 4. ANFis de tahmin edilen günlük buharlașma model performansları

Table 4. Performans of daily evaporation model estimated by ANFIS

\begin{tabular}{ccccc}
\hline Girdiler & $\begin{array}{c}\text { Üyelik } \\
\text { Fonksiyonu }\end{array}$ & $R^{2}$ & RMSE & MAE \\
\hline \multirow{2}{*}{ ANFis, } & trimp & 0.905 & 0.532 & 0.398 \\
& tramp & 0.895 & 0.543 & 0.420 \\
& gausmf & 0.905 & 0.516 & 0.396 \\
& gausmf2 & 0.897 & 0.538 & 0.413 \\
\hline \multirow{2}{*}{ ANFis $_{2}$} & trimp & 0.946 & 0.400 & 0.287 \\
& tramp & 0.939 & 0.424 & 0.308 \\
& gausmf & 0.940 & 0.422 & 0.307 \\
& gausmf2 & 0.956 & 0.360 & 0.203 \\
\hline \multirow{2}{*}{ ANFis $_{3}$} & trimp & 0.978 & 0.252 & 0.157 \\
& tramp & 0.965 & 0.321 & 0.227 \\
\hline
\end{tabular}

Çizelge 5. YSA ve ANFis için en iyi model sonuçları

Table 5. The best model results for ANN and ANFIS

\begin{tabular}{ccccccc}
\hline \multicolumn{3}{c}{ Test Verisi } & \multicolumn{3}{c}{ Eğitim Verisi } \\
\hline \multicolumn{3}{c}{ Amasya } & \multicolumn{2}{c}{ Samsun } & \multicolumn{2}{c}{ Bafra } \\
\hline YSA $^{*}$ & ANFIS* & YSA & ANFiS & YSA & ANFis \\
\hline$R^{2}$ & 0.868 & 0.994 & 0.761 & 0.95 & 0.833 & 0.976 \\
RMSE & 0.713 & 0.124 & 0.684 & 0.282 & 1.228 & 0.229 \\
MAE & 0.661 & 0.072 & 0.491 & 0.140 & 1.060 & 0.133 \\
\hline * 4*8*1 ağ yapısında YSA modeli. ANFis3 gausmf model en iyi \\
model belirlenmiștir.
\end{tabular}

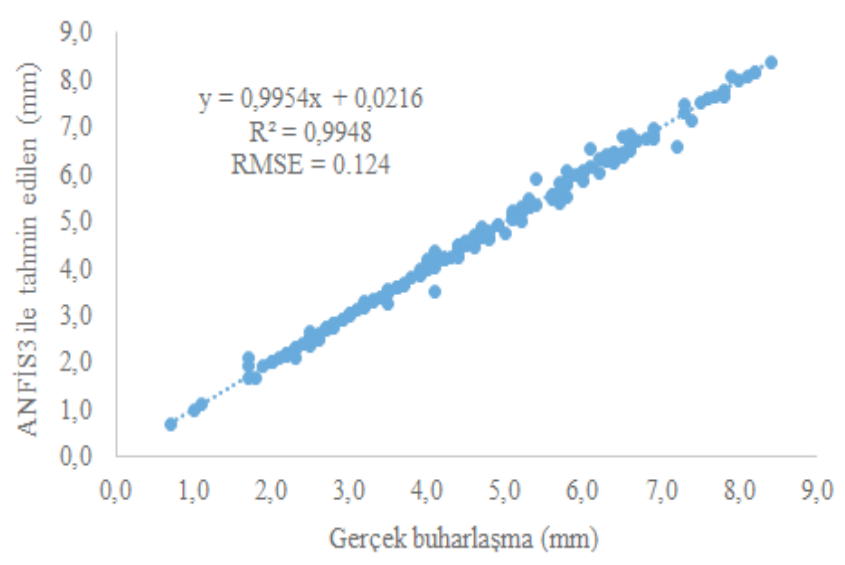

yüksek doğrulukta $\left(R^{2}\right.$ 0.73. RMSE 0.684. MAE 0.491 ) tahmin edilmiștir (Șekil 5-a). Bafra için model performansi' nda $\mathrm{R}^{2}$ 0.833. RMSE 1.22 ve MAE 1.06 olarak hesaplanmıș (Șekil 5-b) ve yüksek doğrulukta günlük buharlașma tahmin edilmiștir. $\mathrm{ANFiS}_{3}$ modeline göre Samsun ve Bafra günlük buharlașma YSA modellerine göre daha yüksek doğrulukta tahmin edilmiștir. ANFis3' e göre Samsun için günlük buharlașma tahminin' de $0.950 \mathrm{R}^{2}$. 0.282 RMSE ve 0.142 MAE performans değerleri elde edilmiștir (Șekil 6-a). Bafra için günlük buharlașma tahmininde belirtme katsayısı $\left(R^{2}\right)$ 0.976. RMSE 0.229 ve MAE değeri 0.133 olarak hesaplanmıștır (Șekil 6-b). Buharlașma tahmininde YSA ve ANFiS modellerinin kullanımı ile ilgili birçok çalıșma yapılmıștır. Afșar 2008. Chung vd., 2012, Kaarimi- Googhari vd., 2012, Boroomand-Nasab ve Joorabian 2011, Atiaa ve Abdal-Oadir (2011) tarafından yapılan çalıșmalarda farklı algoritmalar kullanarak buharlașmanın yüksek doğrulukta tahmin edildiğini belirlemișlerdir. Afșar 2008' de yaptığı te çalıșmasında çok katmanlı yapay sinir ağı. radyal tabanlı yapay sinir ağı, genelleștirilmiș regresyon yapay sinir ağı ve ANFis modellerinde farklı algoritmalar için pan buharlașmasını tahmin etmiș ve farklı istasyonlarda Radyal tabanlı YSA' nın iyi sonuçlar verdiğini belirlemiștir. ANFis modelinin de istasyonda yüksek doğrulukta tahmin yaptığı elde edilmiștir. Antonopoulos ve Antonopoulos, (2017) yaptıkları çalıșmada günlük meteorolojik verileri kullanarak PriestleyTaylor, Makkink, Hargreaves ve kütle transferi ile hesapladıkları referans bitki su tüketimini YSA ile tahmin etmișlerdir. Çalıșmada elde edilen çıktılar yapılan çalıșmalar ile karșılaștırıldığında benzer sonuçlar olduğu belirlenmiștir.

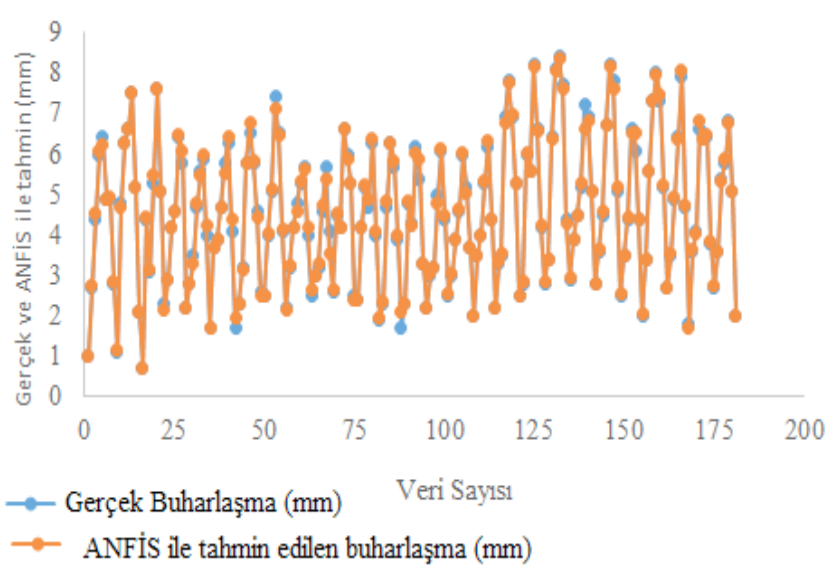

Șekil 4. ANFiS3 ile tahmin edilen gausmf üyelik fonksiyonuna sahip modeli performans grafiği Figure 4. Performans chart of model with gausmf membership function estimated by ANFis3 

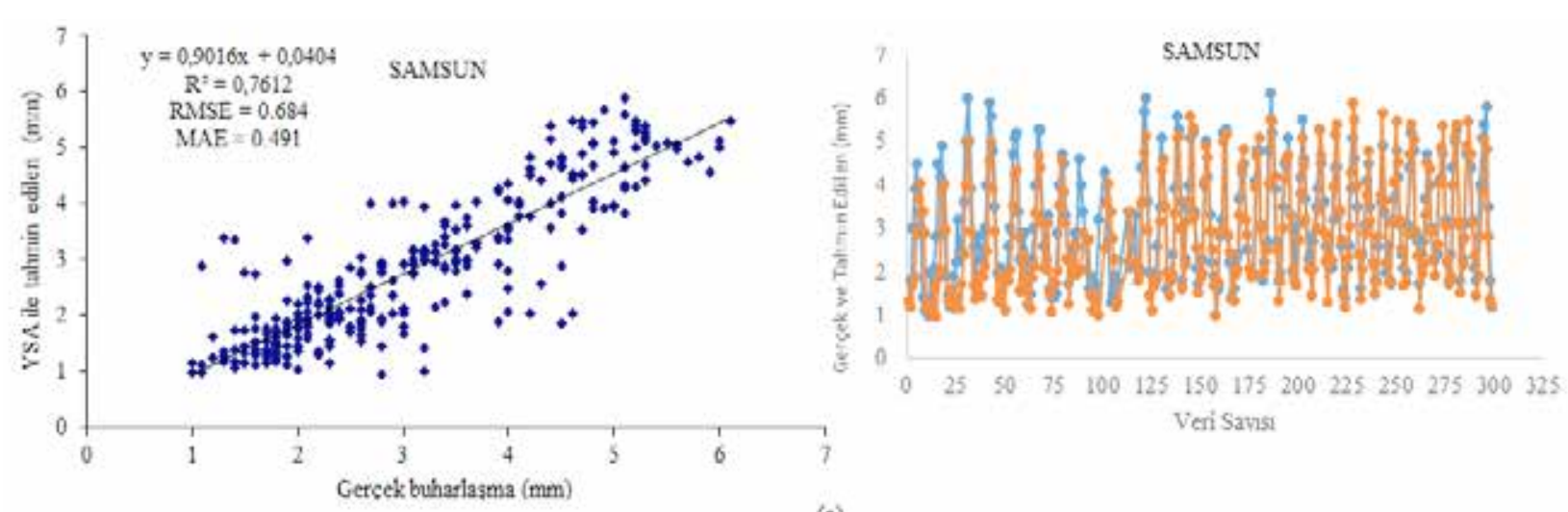

(a)
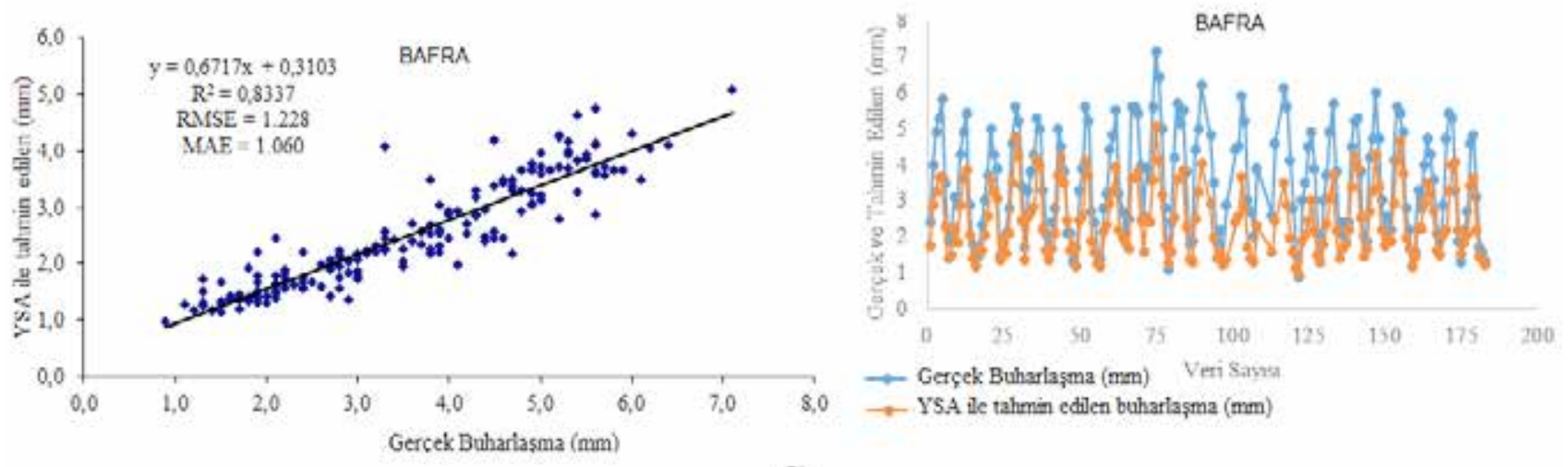

(b)

Șekil 5. YSA2 $4 * 8 * 1$ modeline göre Samsun (a) ve Bafra (b) günlük buharlașma performans sonuçları

Figure 5. Performance results of Samsun (a) ve Bafra (b) daily evaporation according to YSAZ $4 * 8 * 1$ model
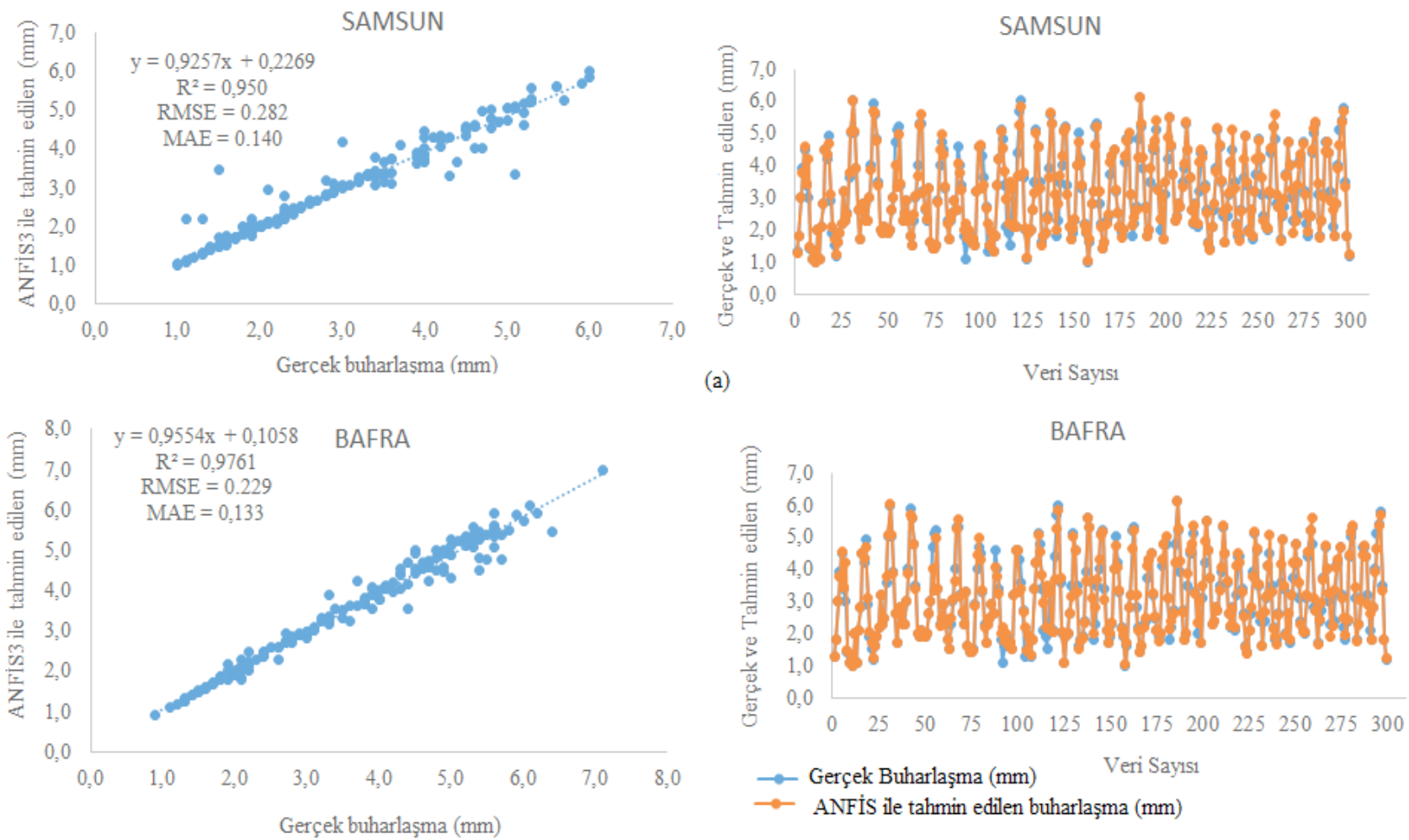

(b)

Șekil 6. $\mathrm{ANFiS}_{3}$ gausmf üyelik fonksiyonuna göre Samsun (a) ve Bafra (b) günlük buharlașma performans sonuçları Figure 6. Performance results of Samsun (a) ve Bafra (b) daily evaporation according to gausmf membership function by ANFIS3 


\section{SONUC̣LAR}

Günlük buharlașmanın tahmin edilmesinde YSA ve ANFis modellerinde farklı kombinasyonlarda girdi ve algoritmalar değerlendirilmiștir. YSA ve ANFiS de $R^{2}$. RMSE ve MAE performans değerleri hesaplanarak en iyi model belirlenmiștir. Samsun ve Bafra günlük buharlașma değerleri model tahmin etmede eğitim verisi olarak ve Amasya günlük buharlașma verileri modeli test etmede kullanılmıștır. YSA' da ortalama sıcaklık, nem, rüzgar hızı ve global güneșlenme verileri girdi olarak kullanımıș ve tek katmanlı $(4 * 8 * 1)$ ağ yapısın' da LM eğitim algoritmasına sahip model için yüksek doğrulukta ( $R^{2}$ 0.86, RMSE 0.713) günlük buharlașma tahmin edilmiștir. $4 * 8 * 1$ ağ yapısında Samsun ve Bafra buharlașma verileri tahmini yapılmıș ve yüksek doğrulukta buharlașma tahmin edilmiștir. ANFiS için ortalama sıcaklık, nem, rüzgar hızı, global güneșlenme ve yağıș girdileri kullanarak $\mathrm{ANFiS}_{3}$ modelinde gausmf üyelik fonksiyonunda en doğru ( $R^{2}$ 0.99, RMSE 0.124) günlük buharlașma tahmin edilmiștir. Bu çalıșma ile günlük buharlașmanın tahmininde YSA ve ANFIS modellerinin kullanılabilirliği belirlenmiștir. YSA ve ANFis modellerini karșılaștırdığımızda ANFis' in daha iyi sonuçlar verdiği görülmektedir. Günlük buharlașmanın ortalama sıcaklık. nem, rüzgar hızı, global güneșlenme ve yağıș girdilerinin kullanarak yüksek doğrulukta tahmin yapılması mümkün olmaktadır.

Günümüzde YSA ve ANFis modelleri ile bazı meteorolojik verilerin ölçümlerinin yapılmaması. hatalıyapılması durumunda ortalama sıcaklık, nem, rüzgâr hızı gibi girdilerin kullanarak buharlașmanın doğru tahmin yapılması ile mümkündür. Bu modeller masrafsız, daha kısa yoldan çözüme ulașan, karmașık verilerin çözümlenmesinde yol gösteren model olup sağılıkı ve bașarıı sonuçların elde edilebileceğini ortaya koymuștur. Çalıșmada kullanılan yöntemler ile tarımsal faaliyetlerin doğru yapılması için su yönetimi, su kullanım stratejileri gibi çalıșmalara katkı sağlayan önemli bulgular elde edilmiștir.

\section{KAYNAKLAR}

Antonopoulos VZ, Antonopoulos AV (2017). Daily reference evapotranspiration estimates by artificial neural networks technique and empirical equations using limited input climate variables. Computers and Electronics in Agriculture. 132: 86-96.
Afșar S (2008). Yapay sinir ağları ve bulanık mantık yöntemleri kullanılarak tava buharlașma tahmini yapılması. İnșaat Müh. ABD. Yüksek Lisans Tezi. Kayseri.

Atiaa AM, Abdul-Oadır AM (2012). Using Fuzzy Logic for Estimating Monthly Pan Evaporation From Meteorological Data in Emara/South of Iraq. J. Baghdad for Sci., 9(1): 133140.

Boroomand-Nasab B, Joorabian M (2012). Estimating Monthly Evaporation Using Artificial Neural Networks. Journal of Environmental Science and Engineering. 5:88-91.

Cemek B, Yıldırım D, Atiș A, Köksal ES, Temizel K (2010). Samsun ili aylık referans bitki su tüketiminin yapay sinir ağlarıyla belirlenmesi. I. Ulusal Su Kaynakları Kongresi. I / s. 44-52. 1-4 Haziran 2010, Eskișehir.

Cemek B, Ünlükara A, Karaman S, Yıldırım D, Atiș A (2011). Marul yetiștirilen topraklarda toprak tuzluluğunun yapay sinir ağları ile belirlenmesi. II. Ulusal Toprak ve Su Kaynakları Kongresi. II / s. 81 1-817. 22-25 Kasım, Ankara.

Chung CH, Chiang YM, Chang FJ (2012). A Spatial Neural Fuzzy Network for Estimating Pan Evaporation at Ungauged Sites. Hydrology and Earth System Sciences, 16. 255-266.

Doğan E, Ișık S (2005). Sapanca Gölü Günlük Buharlașma Miktarının Radyal Temelli Yapay Sinir Ağı Modeli Kullanılarak Tahmin Edilmesi. Bilim Modern Yöntemler Sempozyumu, s. 807-814. Kasım 16-18. Kocaeli. NewYork.

Hebb D (1949). The Organization of Behavior. Willey.

Jang (1993). ANFIS: Adaptive-network-based fuzzy Inference system. IEEE Trans. Syst.. Man. Cybern, 2: 665685.

Jang JS, Sun CT, Mizutani E (1997). Neuro-fuzzy and soft computing: A computational approach to learning and machine intelligence. Upper Saddle River. NJ: Prentice-Hall. 5-15.

Kiși O (2006). Daily pan evaporation modelling using a neuro-fuzzy computing technique, J. Hydrol., 329: 636-646.

Karimi-Googhari S (2012). Daily pan evaporation estimation using a neuro-fuzzy-based model. Journal of Agricultural Science and Technology. 2: 223-228.

McCullogh WS, Pitts WA (1943). A logical calculus of the Ideas Immanent in nervous activity. Bull. Math. Biophysics. Vol. 5: $115-133 \mathrm{p}$.

Sudheer PK, Gosain AK, Mohana RD, Saheb SM (2002). Modeling evaporation using an artificial neural network algorithm. hydrological process. 16:3189- 3202.

Terzi Ö, Keskin EM (2005). Yapay sinir ağları yaklașımı kullanarak günlük tava buharlașmanın tayini. YMO Teknik Dergi. 3683-3693. 